\title{
Intramyocardial bone marrow stem cell transplantation during coronary artery bypass surgery: A meta-analysis
}

\author{
Peter Donndorf, MD, ${ }^{\mathrm{a}}$ Guenther Kundt, $\mathrm{PhD},{ }^{\mathrm{b}}$ Alexander Kaminski, MD, ${ }^{\mathrm{a}}$ Can Yerebakan, MD, ${ }^{\mathrm{a}}$ \\ Andreas Liebold, MD, PhD, ${ }^{a}$ Gustav Steinhoff, $\mathrm{MD}, \mathrm{PhD},{ }^{\mathrm{a}}$ and Aenne Glass ${ }^{\mathrm{b}}$
}

\begin{abstract}
Objective: Experimental and clinical studies have suggested that intramyocardial bone marrow stem cell transplantation combined with coronary artery bypass grafting might improve left ventricular function in the setting of chronic ischemic heart disease. We therefore conducted a systematic review and meta-analysis of available publications regarding the efficacy and safety of intramyocardial bone marrow stem cell transplantation during coronary artery bypass grafting.
\end{abstract}

Methods: The databases PUBMED, MEDLINE, Cochrane Controlled Trials Register, and ClinicalTrials.gov (all from their inception to May 2009) were searched for randomized controlled trials and cohort studies of intramyocardial bone marrow stem cell transplantation during coronary artery bypass grafting to treat ischemic heart disease. Six studies were included.

Results: Compared with control groups, the bone marrow stem cell transplantation group showed a significant improvement of left ventricular ejection fraction from baseline to follow-up $(5.40 \%$; $95 \%$ confidence interval, 1.36-9.44; $P=.009$ ). Moreover, the overall change of left ventricular end-diastolic volume from baseline to follow-up favored the bone marrow stem cell therapy group $(9.55 \mathrm{~mL} ; 95 \%$ confidence interval, -2.82 to 21.92; $P=.13$ ). Major adverse cardiovascular events, including ventricular arrhythmia and the composite of other cardiovascular events, were not significantly different between the bone marrow stem cell therapy group and controls (relative risk for ventricular arrhythmia $=0.951 ; 95 \%$ confidence interval, $0.389-2.325 ; P=.913$; relative risk for cardiovascular event $=1.134 ; 95 \%$ confidence interval, $0.28-4.6 ; P=.86$ ).

Conclusions: Clinical evidence suggests that intramyocardial bone marrow stem cell transplantation in combination with coronary artery bypass grafting is associated with improvements of functional parameters in patients with chronic ischemic heart disease. Furthermore, surgical intramyocardial bone marrow stem cell transplantation seems to be safe. (J Thorac Cardiovasc Surg 2011;142:911-20)

Ischemic cardiomyopathy remains one of the leading causes of morbidity and mortality worldwide. ${ }^{1,2}$ In addition to medical therapy and surgical or interventional revascularization strategies, intramyocardial stem cell therapy has become a new therapeutic option for patients with end-stage ischemic heart disease. Although the exact underlying mechanisms remain unclear, numerous studies in animals have shown that intramyocardial injection of bone marrow stem cells (BMSCs) in ischemic cardiomyopathy is associated with an improvement of left ventricular function and reduction of infarct scar size. ${ }^{3}$ These promising preclinical results led to several clinical trials evaluating possible benefits of stem cell transplantation in humans. Most of these trials, especially when focusing on the treat-

\footnotetext{
From the Department of Cardiac Surgery ${ }^{a}$ and Institute for Biostatistics and Informatics in Medicine and Ageing, Research, ${ }^{b}$ University of Rostock, Rostock, Germany. Disclosures: Authors have nothing to disclose with regard to commercial support. Received for publication July 13, 2010; revisions received Oct 18, 2010; accepted for publication Dec 9, 2010; available ahead of print March 4, 2011.

Address for reprints: Peter Donndorf, MD, Department of Cardiac Surgery, University of Rostock, Schillingallee 35, 18057 Rostock, Germany (E-mail: peter. donndorf@med.uni-rostock.de).

$0022-5223 / \$ 36.00$

Copyright (C) 2011 by The American Association for Thoracic Surgery doi:10.1016/j.jtcvs.2010.12.013
}

ment of acute myocardial infarction, have been carried out using interventional therapy protocols. ${ }^{4}$ Since the first intramyocardial stem cell transplantation during open surgery by Stamm and colleagues ${ }^{5}$ in 2003 , studies that followed were able to prove safety and feasibility of this new therapeutic approach. Subsequently, several prospective, randomized controlled trials (RCTs) were launched to evaluate the efficacy of BMSC injection in addition to coronary bypass surgery compared with coronary artery bypass grafting (CABG) alone in patients with chronic ischemic heart disease. Because chronic ischemic heart disease remains a domain of surgical therapy protocols, ${ }^{6}$ we believe it is reasonable to analyze available studies combining intramyocardial BMSC transplantation with CABG separate from studies using interventional approaches. This article provides a summary and meta-analysis of available prospective RCTs and cohort studies to further evaluate the efficacy of this new therapeutic tool for cardiac surgeons.

\section{MATERIALS AND METHODS \\ Review Question}

The review question was to what extent BMSC transplantation in combination with $\mathrm{CABG}$ affects left ventricular function in patients with chronic ischemic heart disease compared with $\mathrm{CABG}$ alone. 


$$
\begin{aligned}
& \text { Abbreviations and Acronyms } \\
& \begin{aligned}
\text { BMSC } & =\text { bone marrow stem cell } \\
\text { CABG } & =\text { coronary artery bypass grafting } \\
\text { CI } & =\text { confidence interval } \\
\text { LVEDV } & =\text { left ventricular end-diastolic volume } \\
\text { LVEF } & =\text { left ventricular ejection fraction } \\
\text { MACE } & =\text { major adverse cardiovascular events } \\
\text { RCT } & =\text { randomized controlled trial } \\
\text { RR } & =\text { relative risk } \\
\text { SD } & =\text { standard deviation } \\
\text { SE } & =\text { standard error }
\end{aligned}
\end{aligned}
$$

\section{Eligibility Criteria}

Two reviewers (P.D and A.K.) judged the eligibility of studies in duplicate and independently. Eligible trials had to fulfill the following criteria: RCTs or cohort study design comparing routine surgical treatment of chronic ischemic heart disease by CABG with treatment by intramyocardial BMSC injection in addition to CABG; minimum of 3-month followup after stem cell therapy; and intramyocardial injection of BMSCs into ischemic area. Exclusion criteria were intracoronary stem cell injection and catheter-based injection methods; stem cell injection without $\mathrm{CABG}$; treatment of acute myocardial infarction; RCTs and cohort studies with incomplete left ventricular ejection fraction (LVEF) data; and stem or progenitor cells derived from other sources than bone marrow.

\section{Search Strategy}

To identify relevant studies, the electronic databases PUBMED, MEDLINE, Cochrane Controlled Trials Register, and ClinicalTrials (all from their inception to May 2009) were searched with the following databaseappropriate terms: bone marrow, stem cells, progenitor cells, intramyocardial, coronary artery bypass surgery, CABG, transplantation, and trial. Language restrictions were not imposed. Reference lists of identified articles and relevant review articles on the topic were also reviewed. Finally, the included articles were limited to English description, and articles on animal experiments were excluded.

\section{Data Abstraction}

Two reviewers (P.D. and A.K.) independently assessed included studies according to author of the study, year of publication, geographic location of the study, study type, study population, follow-up period, treatment group, control group, LVEF at baseline $\left(\mathrm{LVEF}_{\text {baseline}}\right)$ and follow-up $\left(\mathrm{LVEF}_{\text {follow-up }}\right), \mathrm{LVEF}$ change from baseline to follow-up for the treatment $\left(\mathrm{LVEF}_{\mathrm{BMSC}}\right.$ change $)$ and the control group $\left(\mathrm{LVEF}_{\text {control change }}\right)$, left ventricular end-diastolic volume at baseline ( $\left.\mathrm{LVEDV}_{\text {baseline}}\right)$ and follow-up $\left(\mathrm{LVEDV}_{\text {follow-up }}\right)$, and LVEDV change from baseline to follow-up. Moreover, the number of bypass grafts performed, number of ischemic/akinetic territories, target areas of cell injection, and timing of CABG with combined cell therapy after infarction were assessed (Tables 1-4). The major adverse cardiovascular events (MACE) (Table 5) include ventricular arrhythmias and the composite of other serious cardiovascular events (cardiac death, recurrent myocardial infarction, additional coronary revascularization procedures, and stroke). Relevant data were extracted from the included articles, put into tables, and combined according to the composite outcome definition.

\section{Quality Assessment}

The Jadad Score ${ }^{7}$ was used to grade the methodological quality of the included studies (Table 1).

\section{Statistical Analysis}

For statistical data analysis, STATA 9.0 software (StataCorp, College Station, TX) was used. All $P$ values resulted from 2-sided statistical tests.

The analysis was stratified by the difference between the BMSC group and the CABG control group of every study. Each mean difference was weighted in accordance to the inverse of its variances before being pooled with the fixed-effects model.

Our analyses were based on the 2 parameters mean difference $\mathrm{LVEF}_{\text {change }}$ (with mean difference $\mathrm{LVEF}_{\text {change }}=\mathrm{LVEF}_{\mathrm{BMSC}}$ change $\mathrm{LVEF}_{\text {control change, }} \mathrm{LVEF}_{\mathrm{BMSC}}$ change $=\mathrm{LVEF}_{\mathrm{BMSC}}$ follow-up $-\mathrm{LVEF}_{\mathrm{BMSC}}$ baseline, $\mathrm{LVEF}_{\text {control change }}=\mathrm{LVEF}_{\text {control follow-up }}-\mathrm{LVEF}_{\text {control baseline }}$ ) and mean difference $\mathrm{LVEDV}_{\text {change, }}$, as well as their $95 \%$ confidence intervals (CIs). In most studies, mean and standard deviation (SD) were reported. In one trial, ${ }^{8} \mathrm{LVEF}_{\text {baseline }}$ and $\mathrm{LVEF}_{\text {follow-up }}$ were expressed as mean and standard error (SE). SE was transformed into SD by using the known formula $\mathrm{SD}=\mathrm{SE} \sqrt{ } \mathrm{n}$, with $\mathrm{n}$ being the number of observations.

Unfortunately, mean and SD of the $\mathrm{LVEF}_{\mathrm{BMSC}}$ change and $\mathrm{LVEF}_{\text {control }}$ change were missing in particular studies. ${ }^{8-10}$ Naturally, the mean of

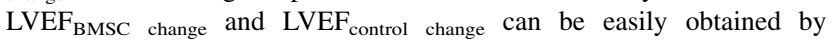
calculating the difference between the means of $\mathrm{LVEF}_{\text {baseline }}$ and $\mathrm{LVEF}_{\text {follow-up. However, available information of measurements of }}$ $\mathrm{LVEF}_{\text {baseline }}$ and $\mathrm{LVEF}_{\text {follow-up }}$ allow valid calculation of SD of change from baseline to follow-up point in time only in case the value of correlation coefficient is known. Therefore, we used the reported SD of

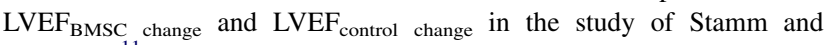
colleagues $^{11}$ to calculate the correlation coefficients, within each group, BMSC and control, by

$$
R=\frac{S D_{\text {baseline }}^{2}+S D_{\text {follow-up }}^{2}-S D_{\text {change }}^{2}}{2 \times S D_{\text {baseline }} \times S D_{\text {follow-up }}},
$$

following Kang and colleagues. ${ }^{12}$

The calculation resulted in $\mathrm{R}=0.45$ for the $\mathrm{BMSC}$ group and $\mathrm{R}=0.85$ for the control group. By imputing these values, we calculated SD of $\mathrm{LVEF}_{\mathrm{BMSC}}$ change and $\mathrm{LVEF}_{\text {control change }}$ for these 3 studies $^{8-10}$ by means of the modified latter formula:

$$
S D_{\text {change }}=\sqrt{S D_{\text {baseline }}^{2}+S D_{\text {follow-up }}^{2}-\left(2 \times R \times S D_{\text {baseline }} \times S D_{\text {follow-up }}\right)} .
$$

Overall homogeneity of the included studies was examined with Cochran's chi-square test and furthermore with $\mathrm{I}^{2}$ for quantifying the effect of heterogeneity by a percentage measure of total variation across studies, which is due to heterogeneity rather than chance. ${ }^{13}$ The decision for application of a fixed-effects model or a random-effects model was made on the basis of the result of Cochran's chi-square test. If evidence of heterogeneity was found, a meta-regression analysis was realized to analyze how factors such as baseline LVEF, age, and sex ( $\%$ male) might alter treatment effectiveness, that is, to estimate interaction between covariate and treatment. To test the statistical significance of the overall effect of all studies, we performed the $z$-test. The presence of publication bias was assessed by funnel plots, Begg's rank correlation test $(\tau)$, and Egger's weighted regression method to quantify asymmetry in funnel plots, if substantial.

For MACE analysis, we calculated relative risk (RR) and the corresponding SE by using the method of Armitage and colleagues ${ }^{14}$ to handle the zero-cells problem.

\section{RESULTS}

Fourteen studies were identified that compared intramyocardial injection of BMSCs in addition to standard revascularization with standard surgical revascularization procedures alone in patients with chronic ischemic heart disease (Figure 1). After more detailed evaluation, 8 studies were excluded from the meta-analysis: Seven studies used 
TABLE 1. Characteristics of included studies

\begin{tabular}{|c|c|c|c|c|c|c|c|c|c|}
\hline $\begin{array}{c}\text { Study } \\
\text { (author, year) }\end{array}$ & $\begin{array}{c}\text { Sample } \\
\text { size }\end{array}$ & $\begin{array}{l}\text { Study } \\
\text { design }\end{array}$ & $\begin{array}{l}\text { Treatment group } \\
\text { (no. and type } \\
\text { of cells } \\
\text { transplanted) }\end{array}$ & $\begin{array}{c}\text { Control } \\
\text { group }\end{array}$ & $\begin{array}{c}\text { Inclusion } \\
\text { criteria }\end{array}$ & $\begin{array}{c}\text { LVEF/LVEDV } \\
\text { evaluation }\end{array}$ & $\begin{array}{c}\text { Follow-up } \\
\text { (mo) }\end{array}$ & $\begin{array}{c}\begin{array}{c}\text { No. of } \\
\text { patients } \\
\text { followed up }\end{array} \\
\end{array}$ & $\begin{array}{c}\text { Jadad } \\
\text { score }\end{array}$ \\
\hline $\begin{array}{l}\text { Stamm and } \\
\text { colleagues } \\
\text { 2007, Germany }\end{array}$ & 40 & RCT & $\begin{array}{l}\text { CD } 133 \text { BMSC } \\
5.80 \times 10^{6} \\
\quad(\text { median })\end{array}$ & CABG only & $\begin{array}{l}\text { History of MI, } \\
\text { indication } \\
\text { for CABG, } \\
\text { akinetic } \\
\text { LV area }\end{array}$ & Echocardiography & 6 & 39 & $4^{*}$ \\
\hline $\begin{array}{l}\text { Hendrikx and } \\
\text { colleagues } \\
\text { 2006, Belgium }\end{array}$ & 20 & RCT & $\begin{array}{l}\text { BMC-MN } \\
\quad 60.25 \pm 31.35 \times 10^{6}\end{array}$ & CABG only & $\begin{array}{l}\text { History of MI, } \\
\text { indication } \\
\text { for CABG, } \\
\text { akinetic } \\
\text { LV area }\end{array}$ & Cardiac MRI & 4 & 20 & $3 * \dagger$ \\
\hline $\begin{array}{l}\text { Ahmadi and } \\
\text { colleagues } \\
\text { 2007, Iran }\end{array}$ & 27 & Cohort & $\begin{array}{l}\text { CD } 133 \text { BMSC } \\
1.89 \pm 0.03 \times 10^{6}\end{array}$ & CABG only & $\begin{array}{l}\text { History of MI, } \\
\text { indication } \\
\text { for CABG, } \\
\geq 4 \text { nonviable } \\
\text { segments in } \\
\text { LAD territory }\end{array}$ & Echocardiography & 6 & 27 & $3 *, \dagger$ \\
\hline $\begin{array}{l}\text { Mocini and } \\
\text { colleagues } \\
\text { 2006, Italy }\end{array}$ & 36 & Cohort & $\begin{array}{l}\text { BMC-MN } \\
292 \pm 232 \times 10^{6}\end{array}$ & CABG only & $\begin{array}{l}\text { History of } \\
\text { MI, CABG } \\
\text { Indication, } \\
\text { nonviable } \\
\text { infarct area }\end{array}$ & Echocardiography & 3 & 36 & $3 * \dagger$ \\
\hline $\begin{array}{l}\text { Patel and } \\
\text { colleagues } \\
\text { 2005, United } \\
\text { States }\end{array}$ & 20 & RCT & $\begin{array}{c}\text { CD } 34 \text { BMSC } \\
22.0 \times 10^{6} \\
(\text { median })\end{array}$ & $\begin{array}{l}\text { CABG only } \\
\text { (off-pump) }\end{array}$ & $\begin{array}{l}\text { Ischemic heart } \\
\text { failure, } \\
\text { LVEF } \leq 40 \%, \\
\text { NYHA III-IV }\end{array}$ & Echocardiography & 6 & 20 & $4^{*}$ \\
\hline $\begin{array}{l}\text { Zhao and } \\
\text { colleagues } \\
\text { 2008, China }\end{array}$ & 36 & $\mathrm{RCT}$ & $\begin{array}{l}\text { BMC-MN } \\
\quad 6.59 \pm 5.12 \times 10^{8}\end{array}$ & CABG only & $\begin{array}{l}\text { History of MI, } \\
\text { akinetic } \\
\text { LV area, } \\
\text { multivessel } \\
\text { disease }\end{array}$ & Echocardiography & 6 & 36 & $4^{*}$ \\
\hline
\end{tabular}

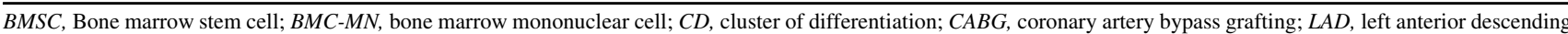
coronary artery; $L V$, left ventricle; $L V E D V$, left ventricular end-diastolic volume; $L V E F$, left ventricular ejection fraction; $M I$, myocardial infarction; $M R I$, magnet resonance imaging; $R C T$; randomized controlled trial; SPECT, single photon emission computed tomography. In Jadad Quality score, the highest total score is 5 . Values are given as mean $\pm \mathrm{SD}$ unless otherwise specified.*Points were deducted from Quality score because the method of blinding was not described or not appropriate. $\dagger$ Points were deducted from Quality score because the method of randomization was not described or not appropriate.

catheter-based endocardial or intracoronary stem cell application methods, and no CABG was performed in one study. Because this restrictive selection process was aimed at emerging as far as possible congruent, and consequently comparable available studies, 6 studies $\left(4 \mathrm{RCTs}^{9,11,15,16}\right.$ and 2 cohort studies ${ }^{8,10}$ ) with a total of 179 patients were included. Four of the 6 studies had a Jadad score of 4, and 2 studies had a Jadad score of 3 (Table 1). The interreviewer agreement on study eligibility was $100 \%$.

\section{Study Characteristics}

The enrolled patients' average age ranged from 48.6 to 64.9 years in the trials, and each trial enrolled mostly men. Notably, the sample size in each study ranged from 20 to 40 patients (median, 32), and the follow-up duration was 3 to 6 months (median, 6 months). The proportion of followed-up patients was more than $98.5 \%$. There was considerable heterogeneity in the timing of CABG with combined cell transplantation after myocardial infarction, ranging from 7 to 84 weeks. In the selected studies, LVEF and LVEDV were evaluated with echocardiography ${ }^{8-11,16}$ or cardiac magnetic resonance imaging. ${ }^{15}$ Assessment of baseline LVEF was performed preoperatively after enrollment for the respective study. There was no significant difference between the control and the treatment groups regarding the number of bypasses. One study did not report the number of grafts performed. ${ }^{8}$ All studies targeted the infarct border zone for stem cell injection; cells were also injected into the infarct area in only 1 study. ${ }^{10}$

\section{Meta-Analysis and Efficacy}

Homogeneity test revealed rejection of null hypothesis of homogeneity for $\mathrm{LVEF}_{\text {change }}$ (Cochran's $\chi^{2}$ test, $P<.001$, Figure 2) and a nonsignificant result for $\operatorname{LVEDV}_{\text {change }}$ (Cochran's $\chi^{2}$ test, $P=.485$, Figure 3 ). Therefore, a random-effects model for $\mathrm{LVEF}_{\text {change }}$ and a fixed-effects model for $\mathrm{LVEDV}_{\text {change }}$ were applied. 
TABLE 2. Perioperative and intraoperative characteristics of studies included in meta-analysis

\begin{tabular}{|c|c|c|c|c|c|c|c|c|c|c|}
\hline \multirow[b]{2}{*}{ Study } & \multicolumn{2}{|c|}{ No. of patients } & \multicolumn{2}{|c|}{ No. of bypasses } & \multicolumn{2}{|c|}{$\begin{array}{c}\text { No. of ischemic/akinetic } \\
\text { territories }\end{array}$} & \multicolumn{2}{|c|}{ Target of cell injection } & \multicolumn{2}{|c|}{ Infarct age (wks) } \\
\hline & Treatment & Control & Treatment & Control & Treatment & Control & Treatment & Control & Treatment & Control \\
\hline $\begin{array}{l}\text { Stamm and } \\
\text { colleagues } \\
\text { 2007, Germany }\end{array}$ & 20 & 20 & $3.3 \pm 1.3$ & $3.6 \pm 0.8$ & $\geq 1$ & $\geq 1$ & Peri-infarct & peri-infarct & $\begin{array}{r}9(2-1200) \\
\quad(\text { median }\end{array}$ & $\begin{array}{l}7.5(2-830) \\
\text { ind range) }\end{array}$ \\
\hline $\begin{array}{l}\text { Hendrikx and } \\
\text { colleagues } \\
\text { 2006, Belgium }\end{array}$ & 10 & 10 & $2.8 \pm 0.4$ & $2.5 \pm 0.5$ & n.a & n.a. & Peri-infarct & peri-infarct & $31.0 \pm 23.2$ & $30.4 \pm 20.7$ \\
\hline $\begin{array}{l}\text { Ahmadi and } \\
\text { colleagues } \\
\text { 2007, Iran }\end{array}$ & 18 & 9 & n.a. & n.a. & $4.78 \pm 0.26$ & $4.67 \pm 0.47$ & Peri-infarct & peri-infarct & $10.5 \pm 0.2$ & $10.6 \pm 0.3$ \\
\hline $\begin{array}{l}\text { Mocini and } \\
\text { colleagues } \\
2006, \text { Italy }\end{array}$ & 18 & 18 & 2.1 . & 3.0 (median) & n.a. & n.a. & $\begin{array}{r}\text { Peri-infarct } \\
+ \text { Infarct }\end{array}$ & $\begin{array}{r}\text { peri-infarct } \\
+ \text { Infarct }\end{array}$ & n.a. & n.a. \\
\hline $\begin{array}{l}\text { Patel and } \\
\text { colleagues 2005, } \\
\text { United States }\end{array}$ & 10 & 10 & $\begin{array}{r}1.1 \pm 0.3 \\
\text { LITA-LAI } \\
\text { addi } \\
\text { vein g }\end{array}$ & $\begin{array}{l}1.0 \pm 0.0 \\
\text { only (19), } \\
\text { tional } \\
\text { raft (1) }\end{array}$ & n.a. & n.a. & Peri-infarct & peri-infarct & n.a. & n.a \\
\hline $\begin{array}{l}\text { Zhao and } \\
\text { colleagues } \\
\text { 2008, China }\end{array}$ & 18 & 18 & $3.68 \pm 1.32$ & $3.75 \pm 1.83$ & $\geq 1$ & $\geq 1$ & Peri-infarct & peri-infarct & $72.0 \pm 66.8$ & $84.0 \pm 72.8$ \\
\hline
\end{tabular}

Our meta-analysis resulted in a significant difference regarding the overall change of the LVEF $\left(\mathrm{LVEF}_{\text {change }}\right)$ from baseline to follow-up between BMSC therapy and control, favoring the BMSC therapy group $(5.40 \% ; 95 \%$ CI, 1.36-9.44; $P=.009$; Figure 2).
Because of evidence for heterogeneity, a meta-regression analysis was realized for $\mathrm{LVEF}_{\text {change. }}$. The regression coefficients are the estimated change in the $\mathrm{LVEF}_{\text {change }}$ per unit change in the covariates. $\mathrm{LVEF}_{\text {change }}$ is estimated to increase by 0.64 per year of age and to decrease by 0.50 per

TABLE 3. Treatment results of studies included in the meta-analysis: Left ventricular ejection fraction

\begin{tabular}{|c|c|c|c|c|c|c|c|c|c|c|c|c|}
\hline \multirow[b]{2}{*}{ Study } & \multicolumn{2}{|c|}{ No. of patients } & \multicolumn{2}{|c|}{ Age (y) } & \multicolumn{2}{|c|}{ Sex, male $(\%)$} & \multicolumn{2}{|c|}{$\begin{array}{c}\text { Baseline } \\
\text { LVEF (\%) }\end{array}$} & \multicolumn{2}{|c|}{$\begin{array}{l}\text { Follow-up } \\
\text { LVEF (\%) }\end{array}$} & \multicolumn{2}{|c|}{$\begin{array}{l}\text { Change of } \\
\text { LVEF (\%) }\end{array}$} \\
\hline & Treatment & Control & Treatment & Control & Treatment & Control & Treatment & Control & Treatment & Control & Treatment & Control \\
\hline $\begin{array}{l}\text { Stamm and } \\
\quad \text { colleagues } \\
2007, \\
\text { Germany }\end{array}$ & 20 & 20 & $62.0 \pm 10.2$ & $63.5 \pm 8.4$ & 75 & 80 & $37.4 \pm 8.4$ & $37.9 \pm 10.3$ & $47.1 \pm 8.3$ & $41.3 \pm 9.1$ & $9.7 \pm 8.8$ & $3.4 \pm 5.5$ \\
\hline $\begin{array}{l}\text { Hendrikx and } \\
\text { colleagues } \\
2006, \\
\text { Belgium }\end{array}$ & 10 & 10 & $63.2 \pm 8.5$ & $66 \pm 9.2$ & 100 & 70 & $42.9 \pm 10.3$ & $39.5 \pm 5.5$ & $48.9 \pm 9.5$ & $43.1 \pm 10.9$ & $6.1 \pm 8.6$ & $3.6 \pm 9.1$ \\
\hline $\begin{array}{l}\text { Ahmadi and } \\
\text { colleagues } \\
\text { 2007, Iran }\end{array}$ & 18 & 9 & $48.6 \pm 9.8$ & $50.9 \pm 4.7$ & 91.6 & 57.1 & $34.3 \pm 6.4$ & $29.2 \pm 7.8$ & $38.0 \pm 5.5$ & $34.3 \pm 8.4$ & $3.7 \pm 6.3$ & $5.1 \pm 4.5$ \\
\hline $\begin{array}{l}\text { Mocini and } \\
\text { colleagues } \\
\text { 2006, Italy }\end{array}$ & 18 & 18 & $64.4 \pm 8.6$ & $66.9 \pm 4.5$ & 94.4 & 94.4 & $46.0 \pm 6$ & $48.0 \pm 8$ & $51.0 \pm 9$ & $49.0 \pm 9$ & $5.0 \pm 8.3$ & $1.0 \pm 4.8$ \\
\hline $\begin{array}{l}\text { Patel and } \\
\text { colleagues } \\
2005, \\
\text { United States }\end{array}$ & 10 & 10 & $64.8 \pm 3.9$ & $63.6 \pm 4.9$ & 80 & 80 & $29.4 \pm 3.6$ & $30.7 \pm 2.5$ & $46.9 \pm 1.9$ & $37.2 \pm 3.4$ & $16.7 \pm 3.2$ & $6.5 \pm 1.8$ \\
\hline $\begin{array}{l}\text { Zhao and } \\
\text { colleagues } \\
\text { 2008, China }\end{array}$ & 18 & 18 & $60.3 \pm 10.4$ & $59.1 \pm 15.7$ & 83.3 & 83.3 & $35.8 \pm 7.3$ & $36.7 \pm 9.2$ & $49.1 \pm 9.7$ & $40.6 \pm 8.4$ & $13.3 \pm 9.2$ & $3.9 \pm 4.9$ \\
\hline
\end{tabular}


TABLE 4. Treatment results of studies included in the meta-analysis: Left ventricular end-diastolic volume

\begin{tabular}{|c|c|c|c|c|c|c|c|c|c|c|c|c|}
\hline \multirow[b]{2}{*}{ Study } & \multicolumn{2}{|c|}{ No. of patients } & \multicolumn{2}{|c|}{ Age (y) } & \multicolumn{2}{|c|}{ Sex, male $(\%)$} & \multicolumn{2}{|c|}{$\begin{array}{c}\text { Baseline } \\
\text { LVEDV }(\mathbf{m L})\end{array}$} & \multicolumn{2}{|c|}{$\begin{array}{c}\text { Follow-up } \\
\text { LVEDV }(\mathbf{m L})\end{array}$} & \multicolumn{2}{|c|}{$\begin{array}{c}\text { Change of } \\
\text { LVEDV }(\mathrm{mL})\end{array}$} \\
\hline & Treatment & Control & Treatment & Control & Treatment & Control & Treatment & Control & Treatment & Control & Treatment & Control \\
\hline $\begin{array}{l}\text { Stamm and } \\
\text { colleagues } \\
2007, \\
\text { Germany }\end{array}$ & 20 & 20 & $62.0 \pm 10.2$ & $63.5 \pm 8.4$ & 75 & 80 & $153.9 \pm 28$ & $153.7 \pm 35$ & $142.8 \pm 42.0$ & $149.3 \pm 35$ & $11.1 \pm 38.6$ & $\overline{4.4 \pm 19.2}$ \\
\hline $\begin{array}{l}\text { Ahmadi and } \\
\text { colleagues } \\
\text { 2007, Iran }\end{array}$ & 18 & 9 & $48.6 \pm 9.8$ & $50.9 \pm 4.7$ & 91.6 & 57.1 & $110.6 \pm 7.5$ & $137.5 \pm 25.7$ & $108.0 \pm 9.6$ & $129.6 \pm 16.6$ & $2.6 \pm 9.17$ & $9 \pm 14.5$ \\
\hline $\begin{array}{l}\text { Patel and } \\
\text { colleagues } \\
2005, \\
\text { United States }\end{array}$ & 10 & 10 & $64.8 \pm 3.9$ & $63.6 \pm 4.9$ & 80 & 80 & $143.0 \pm 29.0$ & $144.0 \pm 23.0$ & $121.0 \pm 26.0$ & $139.0 \pm 22.0$ & $22.0 \pm 27.6$ & $5.0 \pm 12.4$ \\
\hline
\end{tabular}

unit increase of baseline LVEF. Although the association between $\mathrm{LVEF}_{\text {change }}$ and age is of strong statistical evidence (z-test for regression coefficient, $P=.021$ ), the association between $\mathrm{LVEF}_{\text {change }}$ and baseline LVEF could not be detected significantly $(P=.248)$.

Moreover, BMSC therapy showed a trend toward a reduction in LVEDV compared with the control group, with the

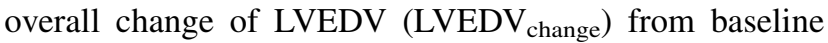
to follow-up favoring the BMSC therapy group $(9.55 \mathrm{~mL}$; $95 \%$ CI, -2.82 to $21.92 ; P=.13$; Figure 3 ).

To exclude potential publication bias, Begg's rank correlation test and Egger's weighted regression test for publication bias were performed. No publication bias was evident for the 6 studies included in LVEF meta-analysis (Begg's rank correlation $P=.573$ for mean difference $\mathrm{LVEF}_{\text {change; }}$; Egger's weighted regression $P=.126$ for mean difference LVEF $\left._{\text {change }}\right)$ or the 3 studies included in the LVEDV meta-analysis (Begg's rank correlation $P=.117$ for mean difference LVEDV $_{\text {change; }}$ Egger's weighted regression $P=.415$ for mean difference $\left.\operatorname{LVEDV}_{\text {change }}\right)$.

\section{Major Adverse Cardiovascular Events}

MACE rates in all 6 studies are described in Table 4. Furthermore, we analyzed the risk ratios of MACE between the BMSC treatment and the control groups (Figures 4 and 5). We found that ventricular arrhythmias and the composite of other cardiovascular events were not significantly different between BMSC therapy and controls $\left(\mathrm{RR}_{\mathrm{VA}}\right.$ : $0.951 ; 95 \%$ CI, 0.389-2.325; $P=.913 ; \mathrm{RR}_{\mathrm{CE}}=1.134 ; 95 \% \mathrm{CI}$, $0.28-4.6 ; P=.86)$, supposing homogeneity $\left(\chi^{2} \mathrm{vA}=1.122\right.$, $\left.d f=5, P=.952 ; \chi_{\mathrm{CE}}^{2}=1.504, d f=5, P=.913\right)$.

\section{DISCUSSION}

This systematic review and meta-analysis, the first, to our knowledge, summarizing the available evidence of intramyocardial BMSC transplantation during $\mathrm{CABG}$ in patients with chronic ischemic heart disease, indicates that BMSC transplantation in addition to $\mathrm{CABG}$ is safe and leads to benefits compared with those achieved by CABG alone. Our results suggest a potential improvement of heart function after intramyocardial BMSC transplantation, indicated

TABLE 5. Summary of reported major adverse cardiovascular events during follow-up

\begin{tabular}{|c|c|c|c|c|c|c|c|c|}
\hline \multirow[b]{2}{*}{ Study } & \multicolumn{2}{|c|}{ No. of patients } & \multicolumn{2}{|c|}{ Follow-up (mo) } & \multicolumn{2}{|c|}{$\begin{array}{l}\text { Ventricular } \\
\text { arrhythmias } \\
\text { (patients) }\end{array}$} & \multicolumn{2}{|c|}{$\begin{array}{l}\text { Composite of cardiac death, } \\
\text { recurrent MI, revascularization } \\
\text { procedure, and stroke (patients) }\end{array}$} \\
\hline & Treatment & Control & Treatment & Control & Treatment & Control & Treatment & Control \\
\hline $\begin{array}{c}\text { Stamm and colleagues } \\
2007, \text { Germany }\end{array}$ & 20 & 20 & 6 & 6 & 0 & 0 & 1 & 0 \\
\hline $\begin{array}{l}\text { Hendrikx and colleagues } \\
\text { 2006, Belgium }\end{array}$ & 10 & 10 & 4 & 4 & 0 & 0 & 0 & 1 \\
\hline $\begin{array}{l}\text { Ahmadi and colleagues } \\
\text { 2007, Iran }\end{array}$ & 18 & 9 & 6 & 6 & 0 & 0 & 0 & 0 \\
\hline $\begin{array}{l}\text { Mocini and colleagues } \\
2006, \text { Italy }\end{array}$ & 18 & 18 & 3 & 3 & 1 & 3 & 0 & 0 \\
\hline $\begin{array}{l}\text { Patel and colleagues } \\
2005, \\
\text { United States }\end{array}$ & 10 & 10 & 4 & 4 & 0 & 0 & 0 & 0 \\
\hline $\begin{array}{l}\text { Zhao and colleagues } \\
\text { 2008, China }\end{array}$ & 18 & 18 & 6 & 6 & 5 & 4 & 1 & 0 \\
\hline
\end{tabular}




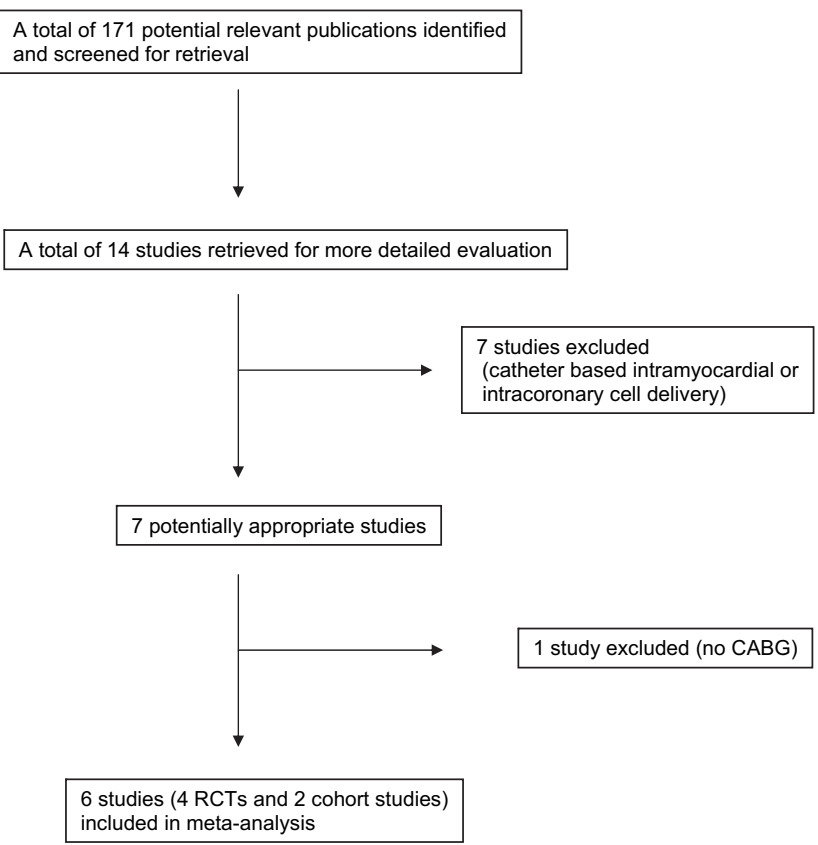

FIGURE 1. Flow chart of eligible studies with BMSC transplantation in combination with $\mathrm{CABG}$ in patients with chronic ischemic heart disease. $C A B G$, Coronary artery bypass grafting; $R C T$, randomized controlled trial.

by improved LVEF. A trend toward reduced LVEDV in the BMSC transplantation group suggests a decrease of cardiac remodeling, however, without reaching statistical significance. In terms of the functional outcome after BMSC transplantation in combination with CABG, our metaanalysis of available studies shows an improvement of LVEF that is significantly higher in the stem cell-treated groups compared with groups treated with CABG only. Meta-regression analysis performed indicates that beneficial functional effects of stem cell therapy in addition to CABG surgery are positively correlated with the amount of preoperative LVEF depression. This underlines the fact that surgical stem cell therapy should primarily focus on patients with indication for CABG surgery and reduced left ventricular function due to chronic ischemia. Notably, the age of patients was found to significantly correlate with functional effects of cell therapy. Because intrinsic myocardial regeneration takes places, but is reduced during a normal life span, ${ }^{17}$ it is conceivable that, in addition to revascularization procedures, elderly patients especially might profit from cell therapy aimed at stimulating regenerative processes.

The improvement of LVEF (mean difference $\mathrm{LVEF}_{\text {change }}$ of $5.40 \%$ ) (Figure 2) in our meta-analysis tends to be higher than in a recently published meta-analysis of intracoronary bone marrow transplantation in the setting of acute myocardial infarction. ${ }^{12}$ This difference in functional improvement might be due to either the different time point of BMSC transplantation (acute myocardial infarction vs chronic ischemic heart disease due to old infarction) or the differing route of cell delivery (intracoronary vs intramyocardial cell application). Early injection after infarction could be

\section{Forest Plot Random Effects}

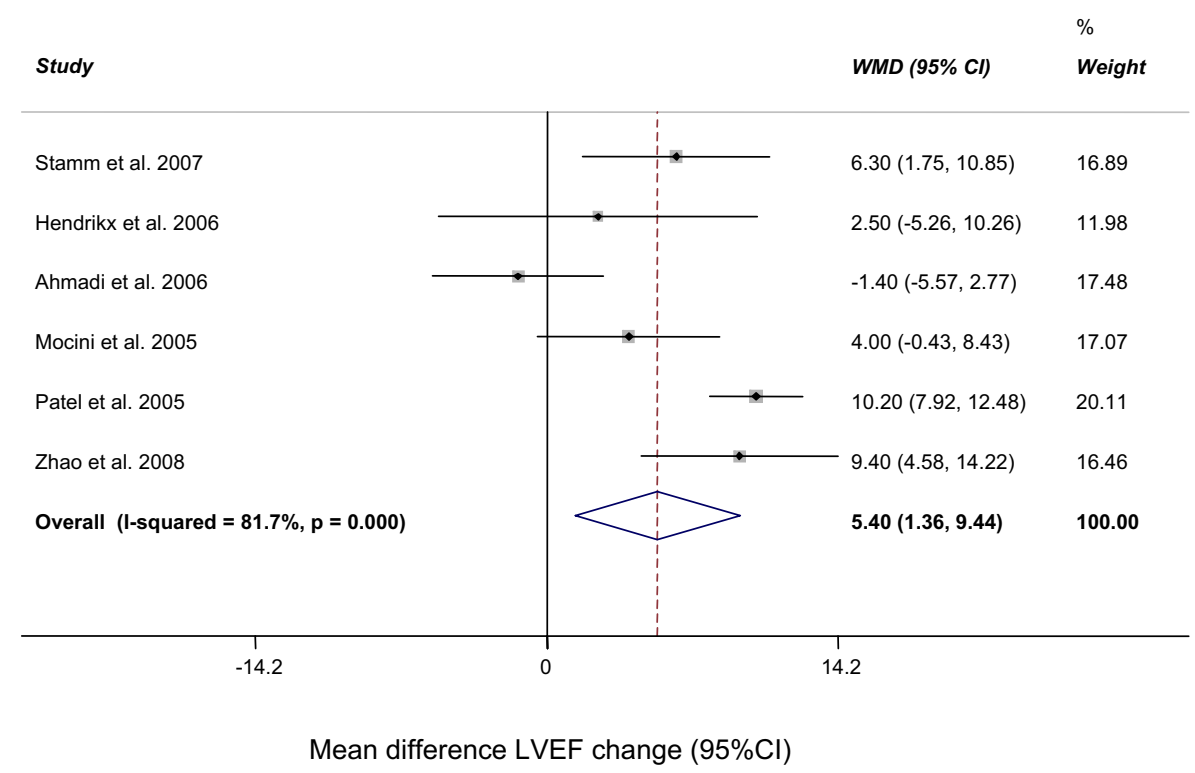

FIGURE 2. Forest plot of difference in mean with $95 \%$ CI shows improvement of LVEF (Mean difference $L_{\text {VEF }}$ change) in patients treated with BMSC compared with control group. Transplantation of BMSC in addition to CABG resulted in a 5.40\% (95\% CI, 1.36-9.44) increase in mean LVEF. The overall effect was statistically significant in favor of BMSC therapy. Sizes of data markers represent the statistical weight each study contributed to the overall random-effects estimate. Heterogeneity: $\chi^{2}=27.28, d f=5, P<.001$, and $\mathrm{I}^{2}$ (variation in weighted mean difference attributable to heterogeneity) $=81.7 \%$; significant overall effect: $z=2.62, P=.009$. 


\section{Forest Plot Fixed Effects}

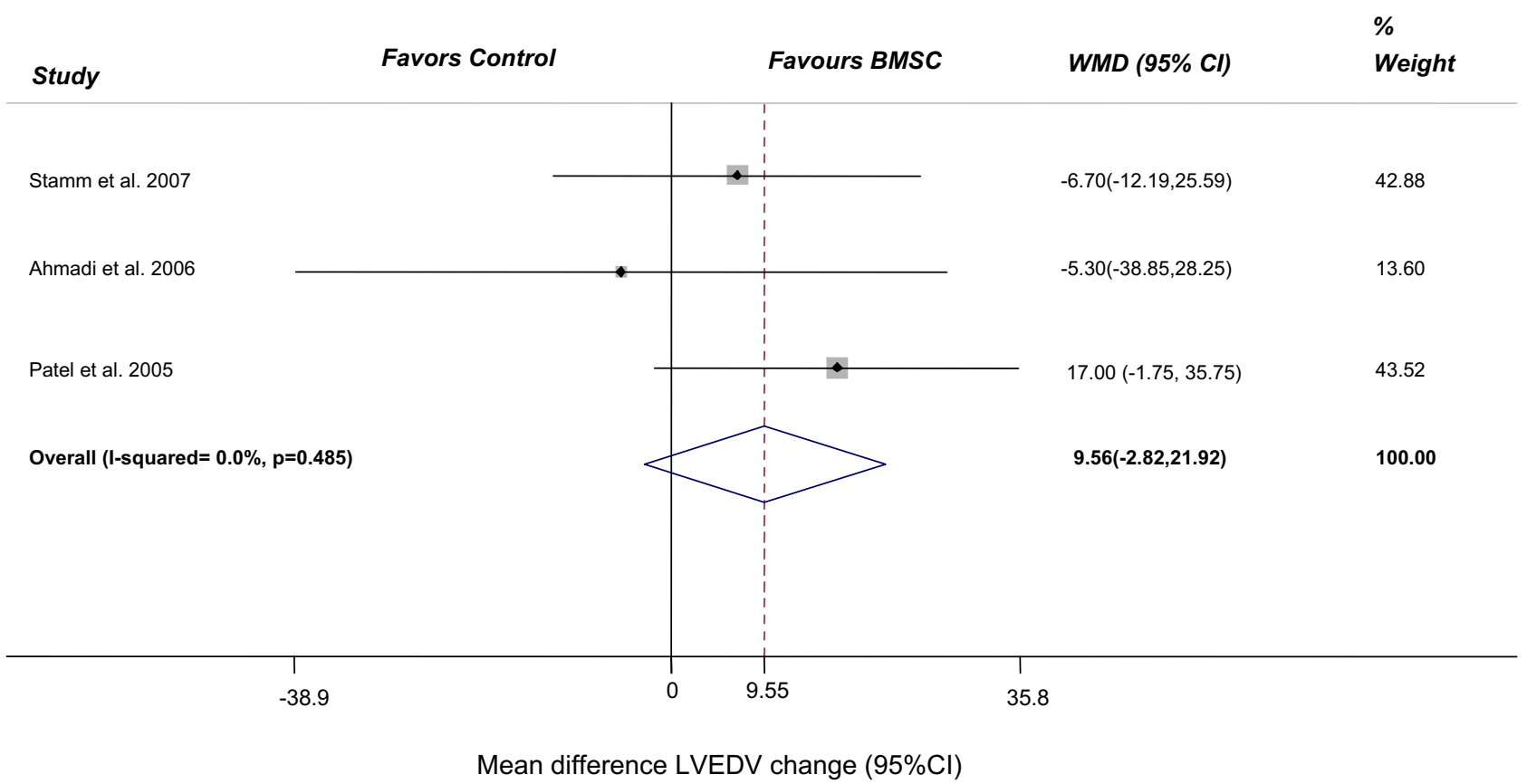

FIGURE 3. Forest plot of difference in mean with $95 \%$ CI shows change of LVEDV (Mean difference LVEDV change $_{\text {) }}$ in patients treated with BMSC compared with control groups. BMSC transplantation in addition to CABG resulted in a 9.55-mL (95\% CI, -2.81 to 21.92) decrease in mean LVEDV. The overall effect favors BMSC treatment (not significant). Sizes of data markers represent the statistical weight each study contributed to the overall fixed-effects estimate. No heterogeneity: $\chi^{2}=1.45, d f=2, P=.485$, and $\mathrm{I}^{2}$ (variation in weighted mean difference attributable to heterogeneity) $=0.0 \%$; significant overall effect: $z=1.51, P=.130$.

\section{Forest Plot Fixed Effects}

Major adverse cardiovascular events Ventricular Arrhythmias

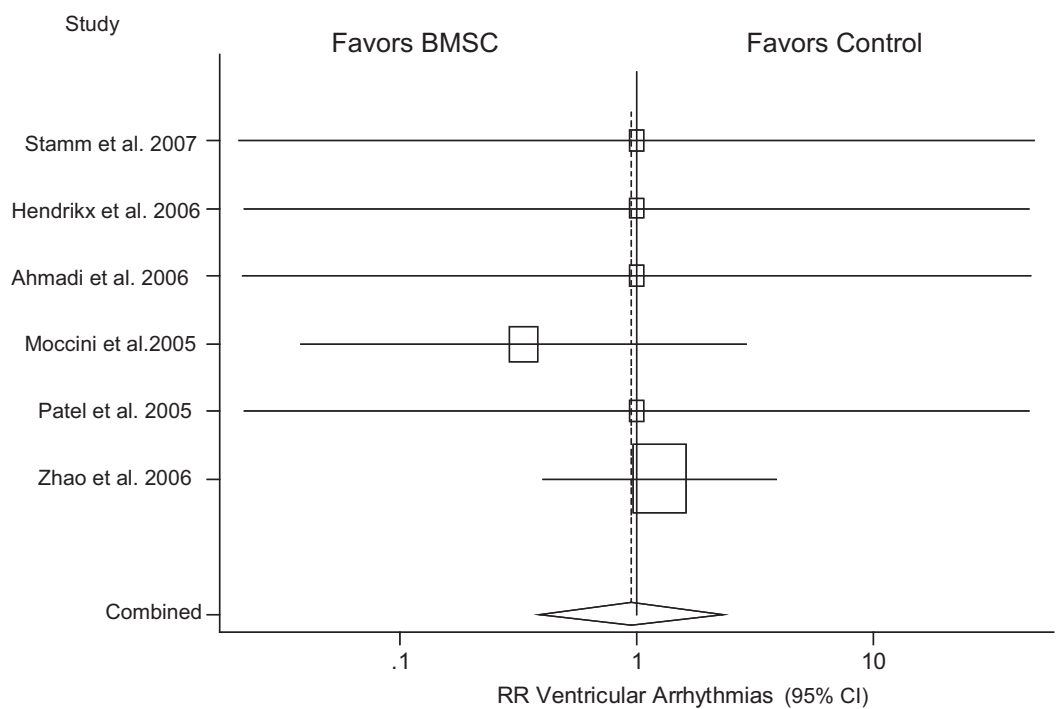

FIGURE 4. Forest plot of RR with the corresponding $95 \%$ CI for ventricular arrhythmias in patients treated with BMSC compared with control group. Sizes of data markers represent the statistical weight each study contributed to the overall fixed-effects estimate. The overall RR shows no significant difference between the 2 groups ( $R R=0.951,95 \% \mathrm{CI}, 0.389-2.325, z=-0.109, P=.913)$, and the included studies are not to be considered inhomogeneous concerning ventricular arrhythmias $\left(\chi^{2}=1.122, d f=5, P=.952\right)$. 


\section{Forest Plot Fixed Effects}

Major adverse cardiovascular events Composite of cardiac death recurrent $\mathrm{MI}$, revascularisation procedure and stroke

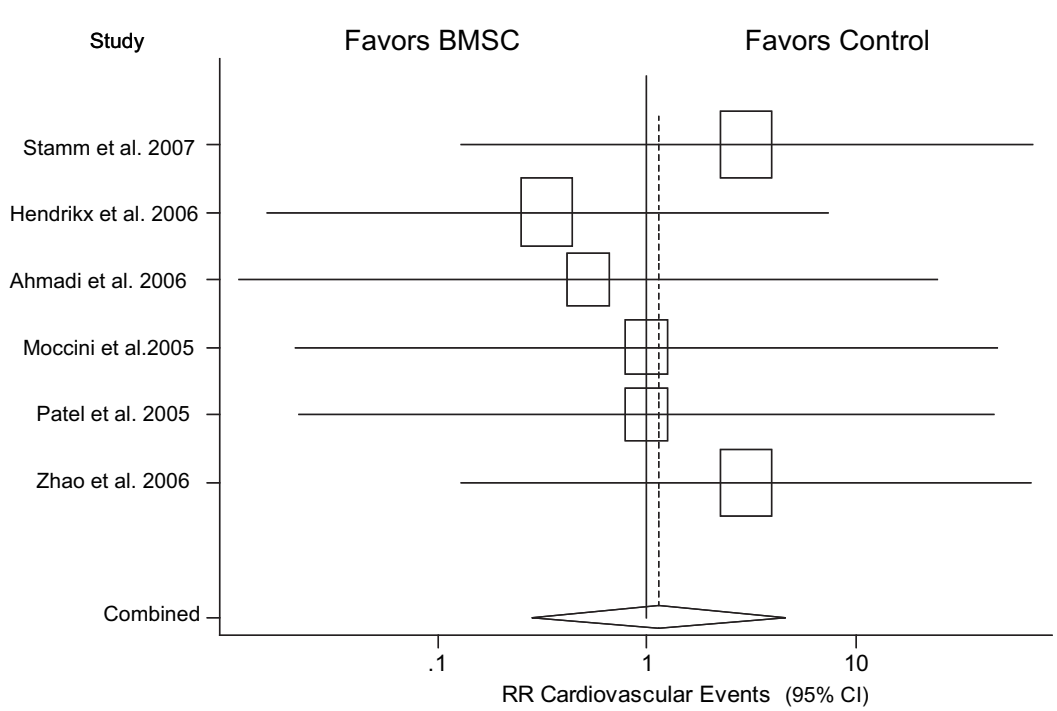

FIGURE 5. Forest plot of RR with the corresponding $95 \%$ CI for the composite of other cardiovascular events (cardiac death, recurrent myocardial infarction, additional coronary revascularization procedures, and stroke) in patients treated with BMSC compared with control group. Sizes of data markers represent the statistical weight each study contributed to the overall fixed-effects estimate. The overall RR shows no significant difference between the 2 groups ( $\mathrm{RR}=1.134,95 \% \mathrm{CI}, 0.28-4.599, z=0.176, P=.86$ ), and the included studies are not to be considered inhomogeneous concerning the composite of other cardiovascular events $\left(\chi^{2}=1.504, d f=5, P=.913\right)$.

beneficial to prevent a large fibrotic scare. On the other hand, because myocardial infarction leads to severe impairment of heart function associated with rhythmic instability and poorer tolerance of additional treatment, it might be reasonable to wait for the acute phase to pass until the infarction zone is consolidated. Furthermore, cell transplantation should be more effective after the postischemic inflammatory reaction has subsided. ${ }^{6,18}$ Stem cell transplantation within the "hot" phase of post-infarction inflammation might lead them to take part in the inflammation cascade rather than in the formation of vessels. ${ }^{19}$ In regard to the route of stem cell delivery, the amount of stem cell recruitment after intravascular cell application is an obvious problem, because preclinical reports describe the myocardial persistence of mononuclear cells from bone marrow after intravascular application as "poor." ${ }^{20}$ Local intramyocardial surgical injection might overcome the problem. In contrast with intracoronary application, stem cells can be delivered directly into the target area of the myocardium without depending on sufficient cell migration across the endothelial barrier, most likely resulting in a decrease of immediate washout and remote organ engraftment of injected cells. ${ }^{21}$ However, except for one study, ${ }^{15}$ all included trials lack placebo injections in the control groups and none of the studies were performed in a double-blinded way. In addition to these methodological advisements, there are further limitations that have to be considered when interpreting the results of our meta-analysis. Because we aimed for evaluating specific surgical stem cell application in combination with CABG, the number of included studies was rather small, gaining an enhanced comparability of studies in return and thus an increased power compared with individual studies. Nevertheless, some different study aspects remained. The methods for evaluating LVEF and LVEDV, the interval between myocardial infarction and CABG, the baseline LVEF, the amount, and the specific type of BMSC used varied among the included studies (Table 1). All of these form potential sources of heterogeneity. The differing baseline LVEF ( LVEF $_{\text {baseline }}$ Table 3) from $29.2 \% \pm 2.6 \%{ }^{8}$ to $48.0 \% \pm 8.0 \%{ }^{10}$ especially limits the interpretation of LVEF data. Future multicenter trials can overcome this problem only by setting up strict inclusion criteria regarding preoperative LVEF. Moreover, 3 of the included 6 studies did not use a specified population of BMSCs but injected a semi-enriched population of bone marrow mononuclear cells. In addition to hematopoietic and mesenchymal stem cells, this population contains leucocytes, making it difficult to attribute functional effects to a certain cell type. Furthermore, because half of the included articles lack complete dimensional left ventricular data, LVEDV change 
was analyzed as qualified in 3 comparable studies. It should be noted that bypass grafting was performed without the use of a heart-lung machine in one study. ${ }^{16}$ Although this offpump approach is of major interest, demonstrating that intramyocardial stem cell injection during CABG can be performed safely without the need for cardioplegic heart arrest, it contributes to methodological heterogeneity. However, the consistency of the beneficial effect of BMSC transplantation regarding LVEF as the primary outcome parameter prespecified in all studies suggests that the association is valid. We believe that combining data from both RCTs and cohort studies to gain adequate statistical power was justified, because all included studies followed the patients prospectively. It was clearly not our aim to give a final judgment regarding the efficacy of intramyocardial cell therapy in combination with CABG but to summarize available evidence to support the ongoing clinical research in the field of surgical stem cell therapy for chronic ischemic heart disease. Only critical analysis of available clinical evidence can detect study heterogeneity and facilitate the design of adequate surgical, double-blinded, randomized, prospective trials because they have been already performed in a larger extent in the field of interventional cardiac cell therapy. To address this issue, the authors recently launched the PERFECT trial, a double-blinded, placebo-controlled, multicenter trial comparing intramyocardial bone marrow $\mathrm{CD}$ $133^{+}$stem cell injection during CABG surgery and CABG in combination with placebo injection. The patient inclusion criteria (see below) were set up after careful review of both their own previous clinical experience ${ }^{6}$ and available clinical evidence. For accurate preoperative evaluation of regional myocardial perfusion deficits, left ventricular function, and consecutive detection of target areas for cell therapy (ie, hibernating myocardium), standardized cardiac magnetic resonance imaging examinations have been established.

PERFECT trial (ClinicalTrials.gov Identifier: NCT00950274)

Patient inclusion criteria:

- Coronary artery disease with indication for $\mathrm{CABG}$ and previous myocardial infarction

- Time frame infarction to cell transplantation more than 2 weeks

- LVEF between $25 \%$ and $40 \%$ measured by cardiac magnetic resonance imaging

- Akinetic/hypokinetic/hibernating left ventricular areas localized by cardiac stress magnetic resonance imaging

\section{CONCLUSIONS}

The results of our meta-analysis suggest that intramyocardial BMSC injection in patients undergoing $\mathrm{CABG}$ for ischemic heart disease is reportedly safe and associated with an improvement of left ventricular functional and modest improvements in dimensional parameters. These improvements are beyond those achieved by standard surgical revascularization alone. Yet, whether the reported gain in left ventricular function leads to long-term clinical improvement in these patients needs to be further clarified. Because the beneficial effects were consistent but studies performed so far are heterogenous and lack adequate blinding and statistical power, our results support the conduct of larger, double-blinded multicenter trials, such as the recently launched PERFECT trial, to further evaluate long-term impact of BMSC transplantation during CABG on cardiac function and clinical outcome in patients with ischemic heart disease.

\section{References}

1. Miller TD, Christian TF, Hopfenspirger MR, Hodge DO, Gersh BJ, Gibbons RJ. Infarct size after acute myocardial infarction measured by quantitative tomographic $99 \mathrm{mTc}$ sestamibi imaging predicts subsequent mortality. Circulation. 1995;92:334-41.

2. Myerburg RJ. Sudden cardiac death: exploring the limits of our knowledge. J Cardiovasc Electrophysiol. 2001;12:369-81.

3. Dawn B, Bolli R. Adult bone marrow-derived cells: regenerative potential, plasticity, and tissue commitment. Basic Res Cardiol. 2005;100:494-503.

4. Abdel-Latif A, Bolli R, Tleyjeh IM, Montori VM, Perin EC, Hornung CA, et al. Adult bone marrow-derived cells for cardiac repair: a systematic review and meta-analysis. Arch Intern Med. 2007;167:989-97.

5. Stamm C, Westphal B, Kleine HD, Petzsch M, Kittner C, Klinge H, et al. Autologous bone-marrow stem-cell transplantation for myocardial regeneration. Lancet. 2003;361:45-6.

6. Kaminski A, Steinhoff G. Current status of intramyocardial bone marrow stem cell transplantation. Semin Thorac Cardiovasc Surg. 2008;20:119-25.

7. Moher D, Jadad AR, Tugwell P. Assessing the quality of randomized controlled trials. Current issues and future directions. Int J Technol Assess Health Care. 1996;12:195-208

8. Ahmadi H, Baharvand H, Ashtiani SK, Soleimani M, Sadeghian H, Ardekani JM, et al. Safety analysis and improved cardiac function following local autologous transplantation of CD133(+) enriched bone marrow cells after myocardial infarction. Curr Neurovasc Res. 2007;4:153-60.

9. Zhao Q, Sun Y, Xia L, Chen A, Wang Z. Randomized study of mononuclear bone marrow cell transplantation in patients with coronary surgery. Ann Thorac Surg 2008;86:1833-40.

10. Mocini D, Staibano M, Mele L, Giannantoni P, Menichella G, Colivicchi F, et al Autologous bone marrow mononuclear cell transplantation in patients undergoing coronary artery bypass grafting. Am Heart J. 2006;151:192-7.

11. Stamm C, Kleine HD, Choi YH, Dunkelmann S, Lauffs JA, Lorenzen B, et al. Intramyocardial delivery of CD133+ bone marrow cells and coronary artery bypass grafting for chronic ischemic heart disease: safety and efficacy studies J Thorac Cardiovasc Surg. 2007;133:717-25.

12. Kang S, Yang YJ, Li CJ, Gao RL. Effects of intracoronary autologous bone marrow cells on left ventricular function in acute myocardial infarction: a systematic review and meta-analysis for randomized controlled trials. Coron Artery Dis. 2008; 19:327-35

13. Higgins J. Measuring inconsistency in meta-analyses. Qual Saf Health Care 2003;327:557.

14. Armitage P, Berry G, Matthews JNS. Statistical Methods in Medical Research. 4th ed. Oxford: Blackwell Science Ltd; 2002.

15. Hendrikx M, Hensen K, Clijsters C, Jongen H, Koninckx R, Bijnens E, et al. Recovery of regional but not global contractile function by the direct intramyocardial autologous bone marrow transplantation: results from a randomized controlled clinical trial. Circulation. 2006;114(1 Suppl):I101-7.

16. Patel AN, Geffner L, Vina RF, Saslavsky J, Urschel HC Jr, Kormos R, et al. Surgical treatment for congestive heart failure with autologous adult stem cell transplantation: a prospective randomized study. J Thorac Cardiovasc Surg. 2005;130:1631-8. 
17. Bergmann O, Bhardwaj RD, Bernard S, Zdunek S, Barnabe-Heider F, Walsh S, et al. Evidence for cardiomyocyte renewal in humans. Science. 2009;324:98-102.

18. Chachques JC. Cellular cardiac regenerative therapy in which patients? Exp Rev Cardiovasc Ther. 2009;7:911-9.

19. Soeki T, Tamura Y, Shinohara H, Tanaka H, Bando K, Fukuda N. Serial changes in serum VEGF and HGF in patients with acute myocardial infarction. Cardiology. 2000;93:168-74.
20. Muller-Ehmsen J, Krausgrill B, Burst V, Schenk K, Neisen UC, Fries JW, et al. Effective engraftment but poor mid-term persistence of mononuclear and mesenchymal bone marrow cells in acute and chronic rat myocardial infarction. $J \mathrm{Mol}$ Cell Cardiol. 2006;41:876-84.

21. Freyman T, Polin G, Osman H, Crary J, Lu M, Cheng L, et al. A quantitative, randomized study evaluating three methods of mesenchymal stem cell delivery following myocardial infarction. Eur Heart J. 2006;27:1114-22. 